\title{
Analytical Comparison Study Between Khabour and Tanjero Formations Northern Iraq
}

\author{
Kamal H. Karim \\ Department of Geology \\ College of Science \\ Sulaimani University
}

(Received 2/1/2006, Accepted 27/4/2006)

\begin{abstract}
Tanjero Formation is one of the best studied stratigraphic units and recently shown to be deposited in foreland basin in different shallow and deep environments. Conversely, Khabour Formation is not studied in detail in term of environment, tectonic and sequence stratigraphy. Therefore, the lower part of the former formation assigned as a norm or model for comparison for the latter one. The comparison is achieved concerning the stratification characteristics; types of trace fossils, type of system tracts, type of environments, source area tectonics and their relation with red beds. The result of this comparison revealed that Khabour Formation, in many aspects, is analogous to lower part of Tanjero Formation. The result of the comparison is showed that Khabour Formation is deposited in different environments include fluvial, deltaic, shelf, slope and deep marine. Among these, now, only the sediments of shelf and slope are cropped out. The thick succession of sandstone with interbeds of shale of this formation is deposited in lowstand system tract forming lowstand wedge. The paleocurrent was possibly toward southwest and the basin may be bordered by active fault during Ordovician. The source area was dioritic or gneissoid body which was possibly weathered in wet climate.
\end{abstract}

\section{درلمة تحليلية شقارنة بين تكوبي الخلبور وتلنجيروفيشمل العراق}

\section{المخاص}

يعد تكوين تانجيرومن أفضل الوحدات الطباقية المدروسة والذيظهر على انه ترسب في حوض مقدمة القارة وفي بيئت مختلفة بعكس تكوين الخابور الذي لم يدرس بشكل كافي من نلحية بيئة التسيب، التتابعلت

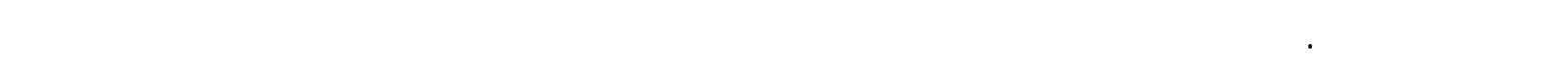
وأنواع أثار المتحجرات وأظمة مسار الترسيب وأنواع البيئت والصخور المصدرية والتكتونية. النتيجة لهذه المقارنة لُٔلهرت أن لتكوين الخابور الفظاهر المشتركة مع الجزء للففلي لتكوين تانجيرو وتبين أن تكوين الخابور قد تربب في بيئت مختلفة من ضمنها النهرية، الدلتاوية، الرصيفية، المنحدرات القارية والبحرية العميقة. من هذه البيئت تنكثف التسببت الرصف والمنحدر القاري فتط في الوقت الحاضر. ترسبت التتبعلت للسميكة من الحجر الرملي مع التدلخل للحجر الطيني أثناء ظلم المسار الوطلئ مكونة وتد المسار 


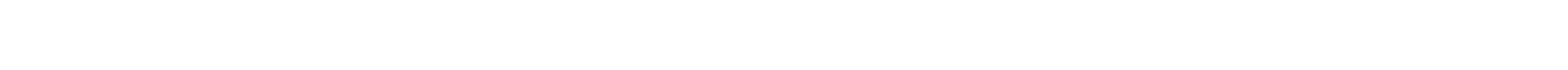

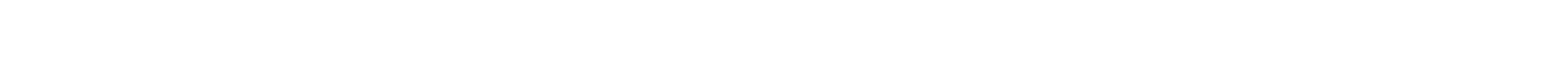
التجوية في مناخ رطب. والورين

\section{INTRODUCTION}

Comparison of criteria, features and processes are widely used in sedimentology, stratigraphy, tectonic and hydrogeology. The comparison of these branches of geology are simplified and standardized by establishing models or norm for comparison. According to Mial (1990, p.166) facies model is powerful tool for poorly exposed sediment. As Khabour Formation has limited outcrops, the well studied Tanjero Formation can be used as a model or standard for comparison to realizing the similarity and dissimilarity of the two formations
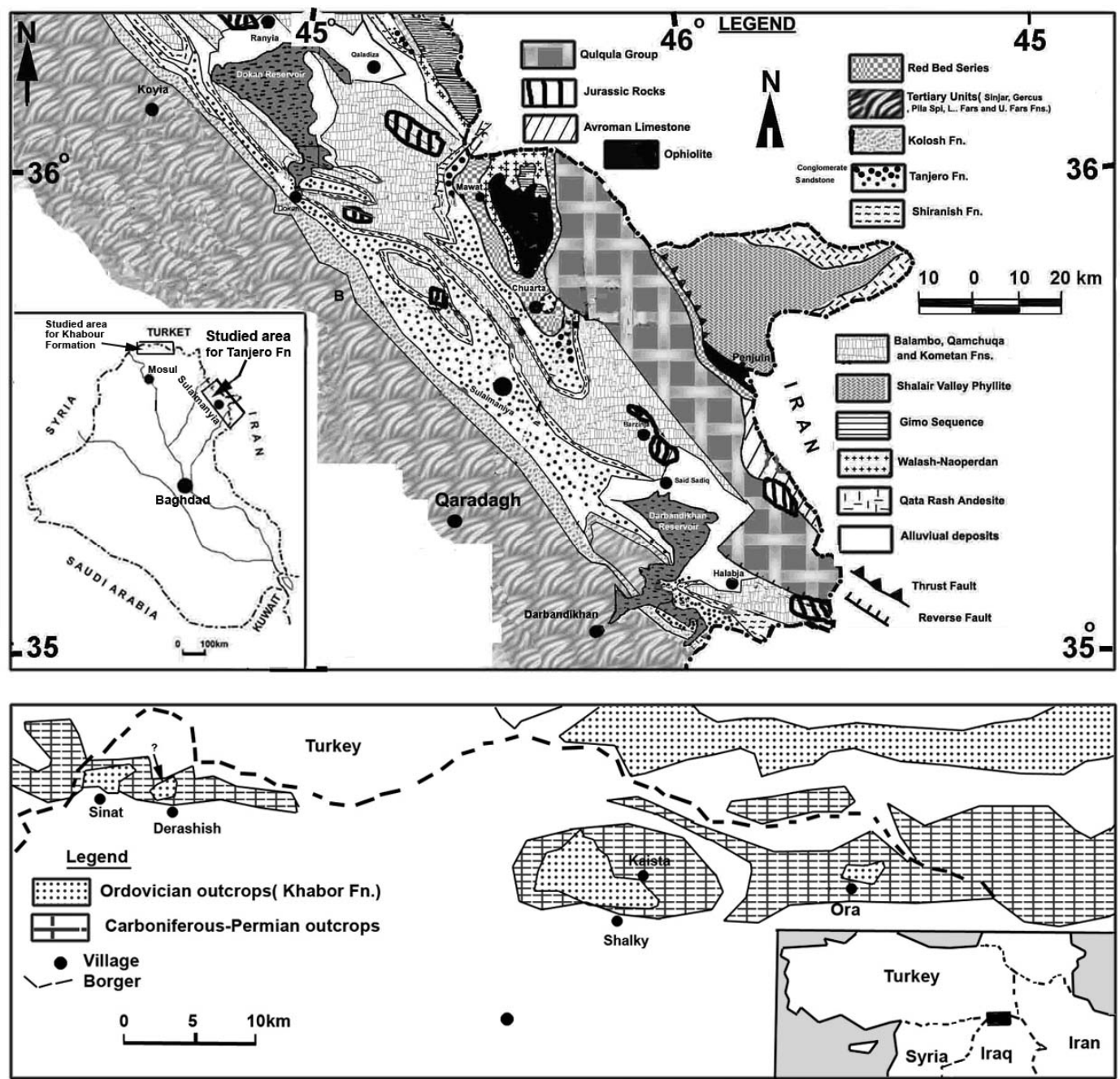

Fig. 1:Upper Map: Location and Geological map of the outcrops distribution of the Tanjero Formation in Sulaimanyia area modified from (Jassim et al, 1987). Lower map: Geological map of the outcrops distribution of the Khabour Formation in the Dohuk area modified from (Al-Omari and Sadiq 1977). 
with respect to environment, tectonic setting, and sequence stratigraphy. The reasons of the comparison as follows:

1-Tanjero Formation is well studied formation in all aspect among those studied we mention, Al-Rawi, 1980, Abdul-Kareem, 1986b, Jazza, 1991, Lawa et al, 1998, Al-Rawi and Al- Rawi, 2002, Karim, 2004. Karim, 2005, Karim and Surdashy, 2005a, Karim and Surdahy, 2005b, Karim and Surdahy, 2005c). In contrast to these, the only study on the Khabour Formation in outcrops is the classical study of Wetzel (1950 in Bellen, et al , 1959) and Seilacher (1963) in addition to few new studies such as Al-Juboury and Al-Hadidy (2001a, b). The last two studies are conducted on bore holes samples in Akkas well of Iraqi Western Desert.

2-In the last three studies of the Tanjero Formation, models for stratigraphy, sequence stratigraphy, tectonic and depositional environment are drawn. This is attributed to more availability of the outcrops in Iraq as compared to Khabour Formation (Fig.1).

3- On the basis of main lithological distribution Karim (2004) divided Tanjero Formation in to three parts (lower, middle and upper parts). According to this study, the lower part was deposited in a shallow environment as lowstand system tract which consisted of thick wedge of $500 \mathrm{~m}$ conglomerate and about $400 \mathrm{~m}$ sandstone at the near shore area and on the slope of the basin respectively. He showed that the sandstone is deposited by processes of turbidity current and storm, forming turbidite and tempestite respectively. The middle part (middle transgressive part) is composed of 100-300m of bluish white marl and calcareous shale. The upper part consists of alternation of biogenic limestone and calcareous shale with minor amounts of sandstone and conglomerate. He also proved that the basin was a foreland basin. He called it "Early Zagros Foreland Basin". Field study showed that characteristics of the lower part of Tanjero Formation can be used as a model for comparison with Khabour Formation.

\section{Analysis of Khabour Formation by comparison with Tanjero Formation}

The comparison is based on the fact that the lower part of Tanjero Formation was deposited in different environments ranged from continental (fluviatile and deltaic) to shelf and slope environment. This is proved by Karim (2004 and 2005) in term of sedimentary structures and trace fossils. So the similarity and dissimilarity of the lower part of the Tanjero Formation with that of Khabour Formation is discussed in detail as follows:

\section{Comparison of stratification characteristics}

When one observe, in most places, both formations in the field, no clear difference can differentiated between the two formation as concerned to color, bed thickness and bed couplets. As concerned to color, both have grey color with some brown tint on the weathered surfaces. The thickness of the sandstone beds are ranged, in most places, from $5 \mathrm{~cm}$ to $1 \mathrm{~m}$, in addition to that both consist of thick successions of sandstone and shale couplets (Fig.2, 3 and 4). This type of lithologies are mentioned in Khabour Formation by Buday (1980), Bellen et al (1959, p. 147) and Al-Juboury and Al-Hadidy (2001a). 
The layers of both formations, in most cases, have long lateral extent. The thickness of both formations is nearly equal (more than $500 \mathrm{~m}$ ). Both formation contain cross bedding and similar ripple marks Fig.(10A and B). In this connection, Bellen (op. cit) and Al-Juboury and Al-Hadidy (2001a), recorded cross bedding and ripple marks respectively in the Khabour Formation; the same structures are also recorded in the Tanjero Formation (Fig.3A). Karim, (2005a) has attributed these layers to either turbidity current or storm deposits. He suggested that storm reworked shelf and delta sediments and re-deposited in the near by places as tempestite or transported to deep water slope by turbidity current and deposited as turbidite. Turbidite mode of deposition was indicated also cited in the Khabour Formation by Seilacher (1963 in Buday, 1980) who mentioned that the environment of the formation gradually changed upwards to a relatively deeper, turbidite affected facies. In addition the successions of Tanjero and Khabour Formations are overlain (in some place) by Red Bed Series and Pirispiki Red Beds respectively (Fig.2). This means that both formations are changing from marine to near shore facies or even continental ones.

\section{Tectonic and lithologic comparison}

As mentioned before, both formations are overlain by red beds (Pirispiki and Red Bed Series), this indicates the shallowing upward from relatively deep marine to near shore (or even terrestrial) lithologies (Fig. 2 A and C). According to Mial (1990), sediment, in foreland basins shallows up from deep water to shallow marine and then to continental sedimentation. Doyle et al., (2001, p.111) also mentioned that the sediments of foreland

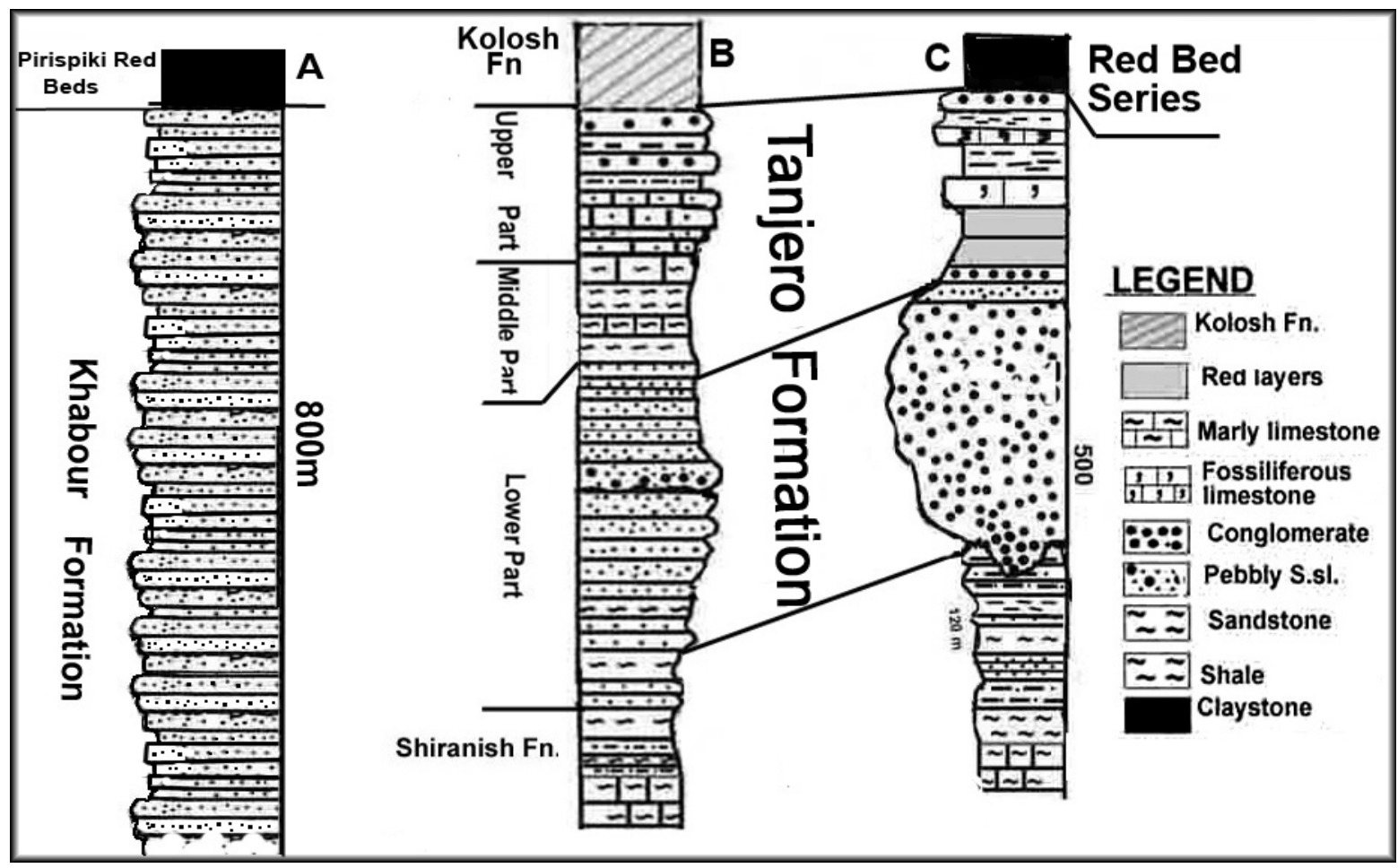

Fig. 2 : The lithological column of Khabour Formation (A) and Tanjero Formation in distal area (B) and proximal area in Dokan area and south of Sulaimanyia city (C).The lower part of this formation is only comparable with former formation. 


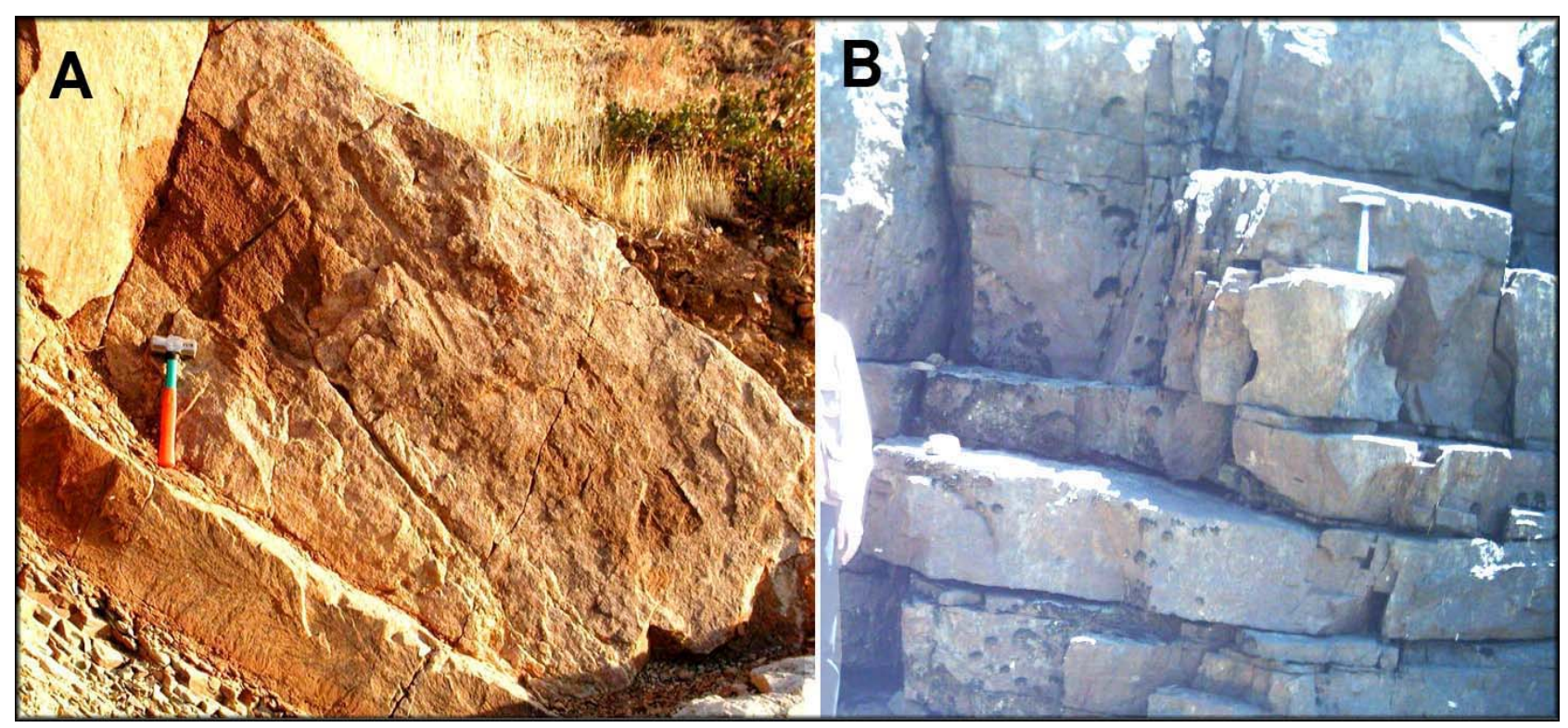

Fig. 3: A) Cross bedded sandstone in Tanjero Formation, exposed along road cut, $1 \mathrm{~km}$ north of Sulaimanyia city.

B) Beds of 1meter thickness in Khabour Formation found near Kaista village.

basin are deposited mostly in river and deltaic environment and consist of heterogeneous gravel, sands and mud derived from orogenic belt. These ideas are applicable for Tanjero Formation. While the high thickness of the Khabour Formation and the overlying Pirispiki Red Beds and volcanic rocks (Chalki volcanics) may indicate high tectonic effect (at least at Khabour area) in a fault bounded basin. The fault most possibly was a rifted or normal fault occurred before the deposition of Khabour Formation, the reason for this is that this type of faulting is attributed to basin extension.

Thin section study showed, that the lithology of the Khabour Formation is dominantly 85\% of terrigenous monocrystalline quartz (Fig. 5A, B and C) with some weathered biotite grains. About $70 \%$ of the quartz grains have straight extinction while others are undulatory extinction. The sandstone of the formation show intense compaction as most grains have well developed sutured contact relation (Fig.5A, B and C). It is possibly that most of the undulatory grains were affected by overburden stress as shown from well developed sutured contact which is, in some case, developed to microstylolite (Fig.5C). According to these facts the source area, most possibly, belong to diorite or gneissoid terrain with wet climate. Al-Juboury and Al-Hadidy (2001b), showed that source area of Khabour Formation in Iraqi Western desert is granitic or low rank metamorphic rocks. Therefore and according to this study and that of Khabour area in outcrops, it is possible that the source area of Khabour Formation is changing according to geographic locations. The similar facts is recorded for Tanjero Formation by Karim (2004) who cited that the source area for lower part of the Tanjero Formation is mainly consisted, in Sulaimanyia area, of cherts and bituminous limestones of Qulqula Formation while toward in Qandil area toward northwest share of ophiolite increase. 


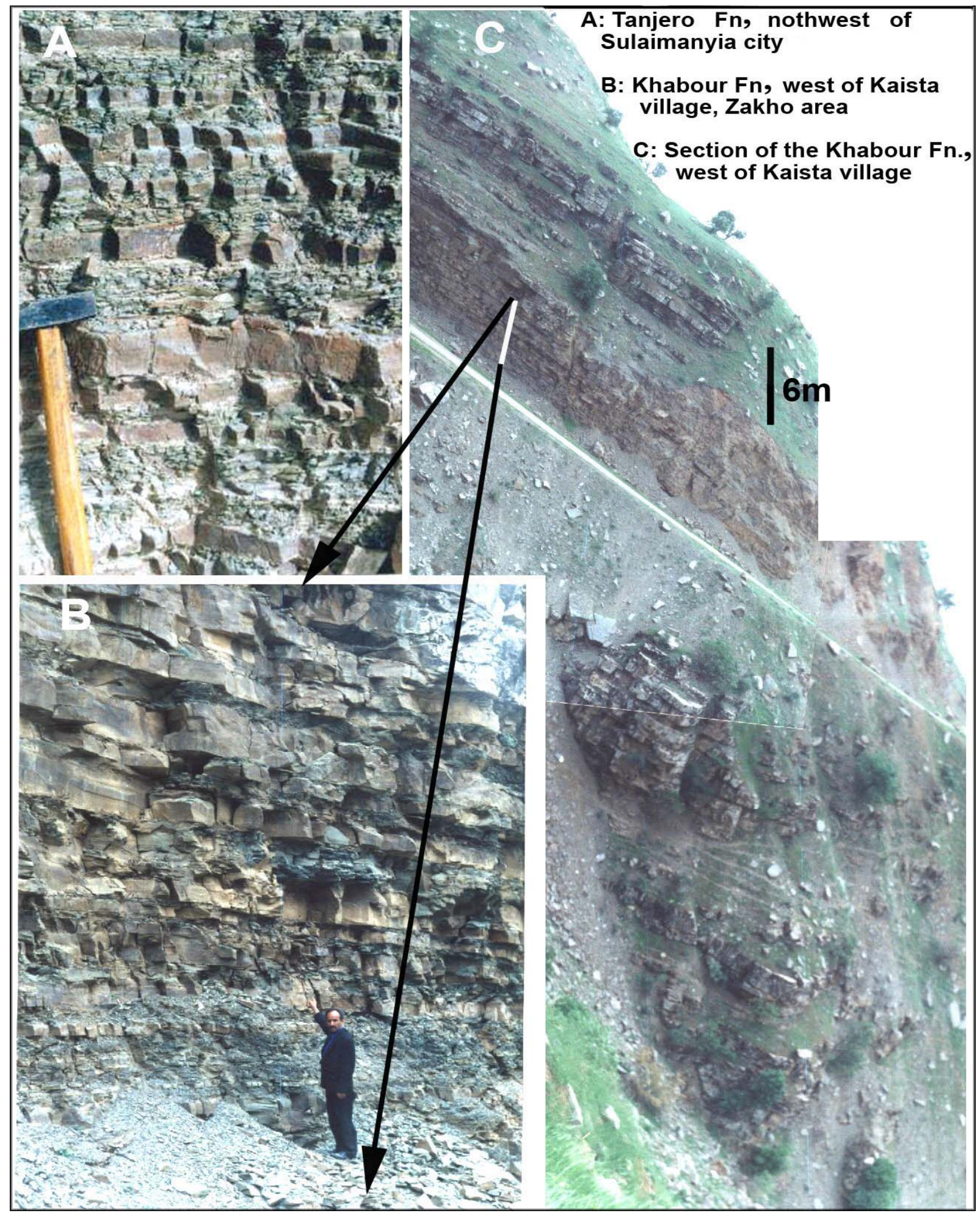

Fig. 4: Similarity of the stratification characteristic (bed thickness, color and associated couplets of shale and sandstone) of the Khabour and Tanjero Formations. 

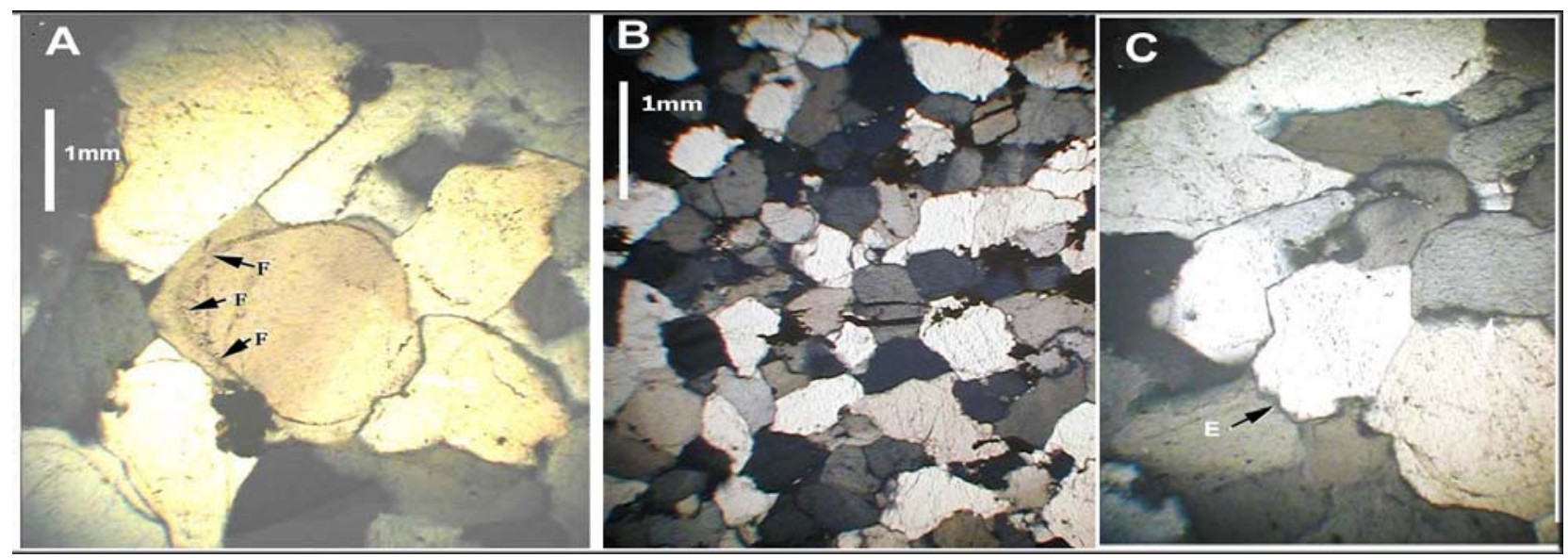

Fig. 5: Three thin sections (under plane polarized light) of the Khabour sandstone. Arenite of Khabour Formation composed mainly of quartz grains with well developed sutured contacts (E) and grains overgrowth (F).
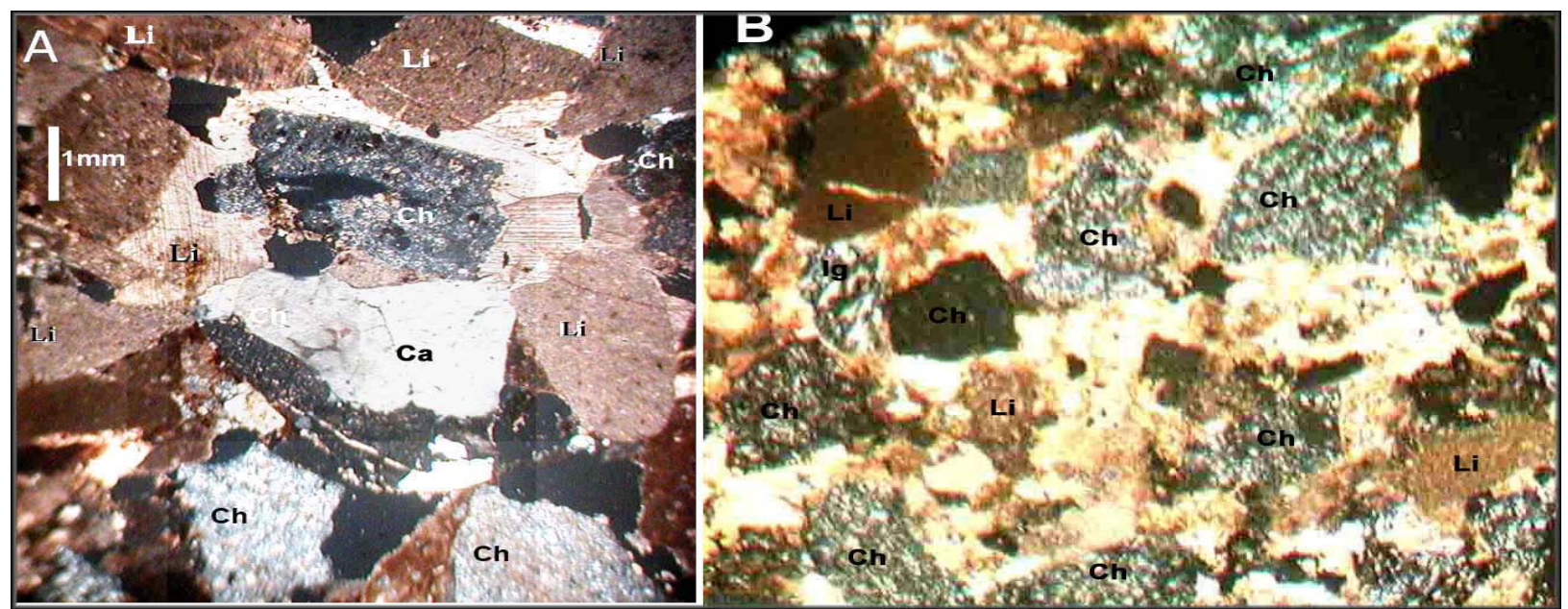

Fig. 6: Two thin sections (under plane polarized light) of sandstone of the lower part of Tanjero Formation. A) Lithic arenite of Tanjero Formation north of Sulaimanyia city, consist of chert $(\mathrm{Ch})$, limestone $(\mathrm{Li})$ and calcite $(\mathrm{Ca})$ clasts.

B) Lithic arenite at Dokan Area, containing chert and limestone and altered gabbro or peridotite( Ig).

The results of the thin section study and point counting are plotted on the triangles of Dickinson et al (1983) and Pettijohn (1975) Fig.(7). This plotting is intended to classify of the sandstones and finding the tectonic setting of the source areas of the two formations. The position of the terrigenous grains of the sandstone in Tanjero Formation shows uplifted orogen which means folded foreland or uplifted subduction sediments and ophiolites. The clasts are mainly consisted of chert and bituminous limestone with minor amount of quartz and igneous rocks. On the other hand, the position of the grains of Khabour Formation (left triangle in the fig.7) revealed that the source area is craton. 


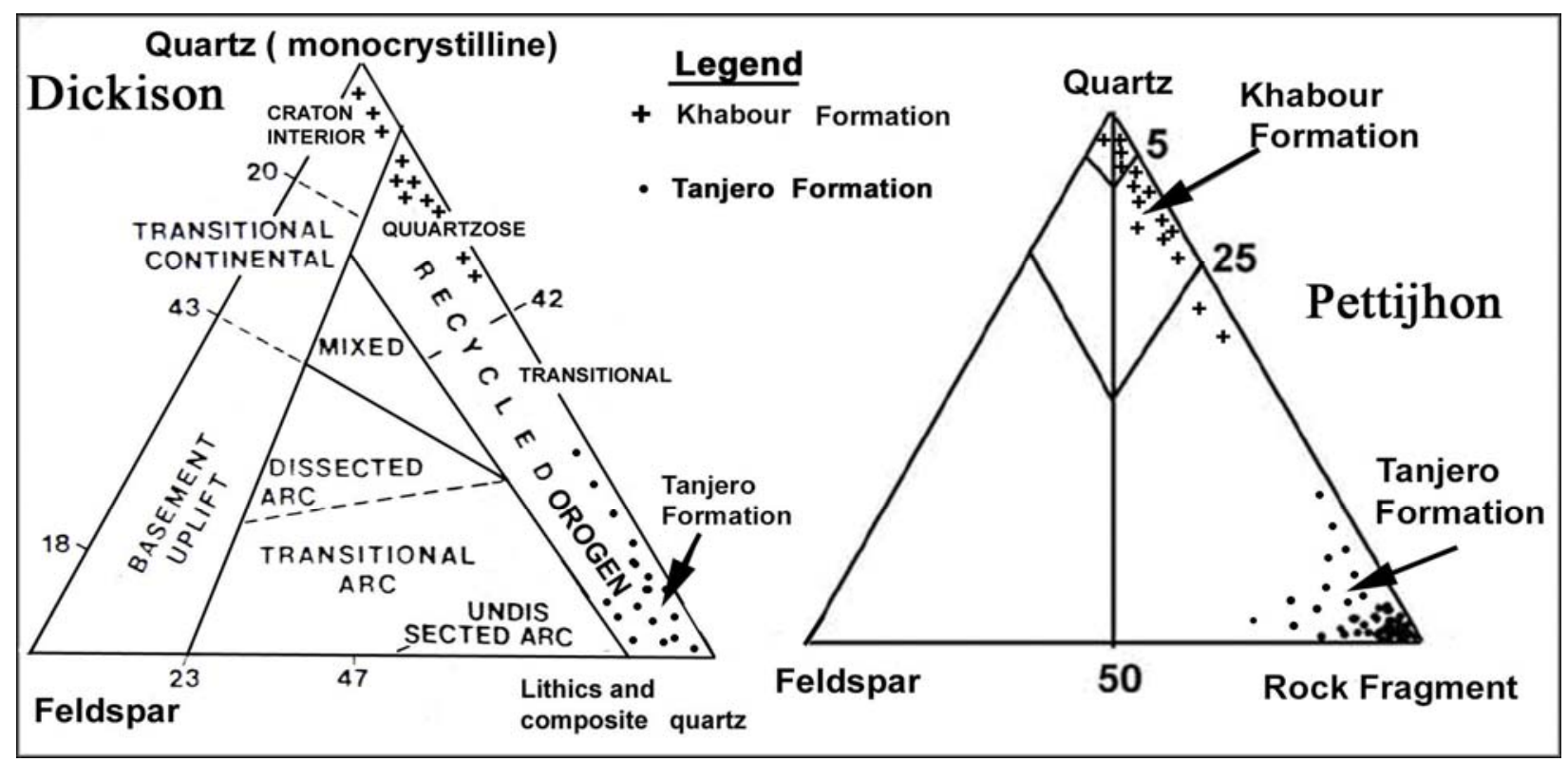

Fig. 7: Plotting of sandstone of the Tanjero Formation and Khabour Formation on the triangles of Dickinson et al., (1983)( left) and Pettijohn (1975) for tectonic setting and classification of sandstones respectively (right).

\section{Trace fossil comparison}

In the field and around Kaista village clear cruziana can be seen in the Khabour Formation (Fig.1 and 4) which indicates trail trace and scouring of trilobite on the surface of muddy or sand substrate. In the Tanjero Formation, recently many traces fossils (returned to planolite and or cruziana assemblage) are found which more or less similar to that of Khabour Formation. Karim (2005c) classified them as planolite (Fig.5A and B) which consist of straight and horizontal or slightly curved burrows. Most of them have smooth surface while few have side ridges (Fig. 9A and B). According to Kennedy (1975) these traces belonge to Thalassinoides and Planolite trace fossils which are included in Cruziana assemblage by him. In the Tanjero Formation, most of planolite trace fossils are attributed to either pelecypods or gastropods (Fig.9B). Karim (2004, 2005c) cited the following points for including these trace in cruziana ichnofacies:

1-They exist, as cruziana, in coarse and medium grained sandstones and they resemble them except in the lack of striate markings on the lobes (flanks) (Fig.9B).

2-They exist in the lower part of the formation, which contains coarsest sediment (thick boulder conglomerate) therefore the trace left by organism more or less in shallow water during sea level fall.

\section{System tract comparison}

According to the sedimentary structures found by Karim (2005c), the lower part of the Tanjero Formation is deposited in shallow environment. While Karim and Surdashy (2005b) showed that this part consists of lowstand wedge (lowstand system tract) which deposited during sea level fall. They mentioned that the lithology of this system tract represents the typical lithology of the formation. This typical lithology consists of alternation of thin beds 


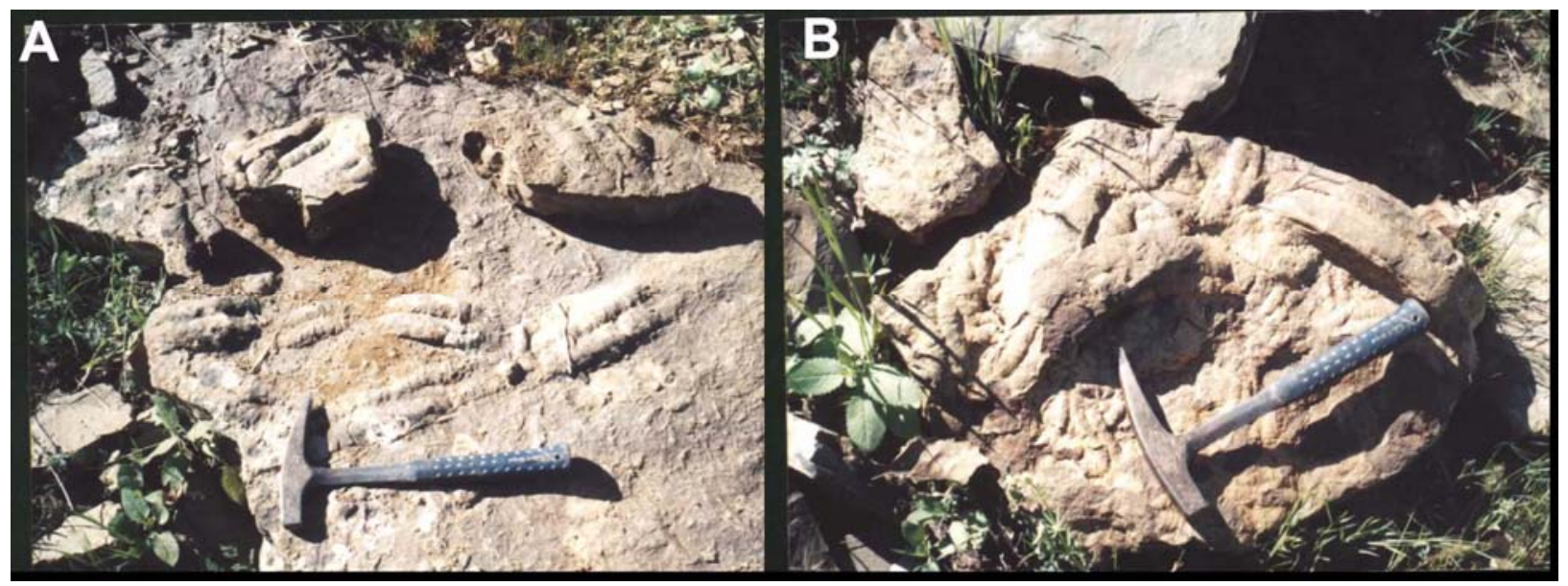

Fig. 8: Cruziana trace in the Khabour Formation found at the west of Kaista Village, Zakho area.

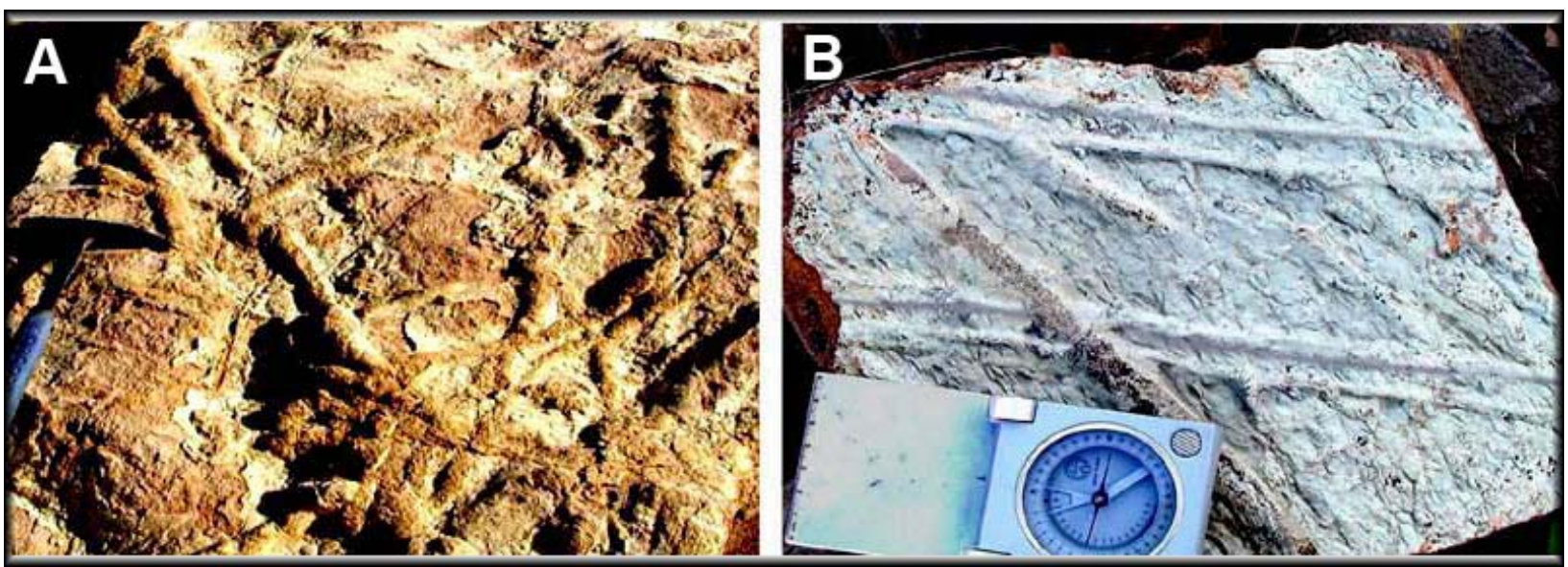

Fig. 9: Two types of Planolite trace fossils in the lower part of the Tanjero Formation, B) found at $1 \mathrm{~km}$ north of Sulaimanyia, B) found at $2 \mathrm{~km}$ west of Mara Rash village , $10 \mathrm{~km}$ south of Mawat Town ( taken from Karim, 2005.)

of sandstone and shale which studied previously in detail by Al-Rawi (1980), Jaza (1991) and Karim (2004). The last author inferred the wedge shape of the system tract by field tracing of the sandstone across paleoslope (from Chuarta area to south of Sulaimanyia City. He found, on the shelf rare sandstone which exist as package no more than $10 \mathrm{~m}$ thick) while on the slope it reaches $400 \mathrm{~m}$. He also observed that it thin again on the basin plain (south of Sulaimanyia city). The reason for absence of sandstone on the shelf (Chuarta-Mawat area) is due to bypassing to the slope by submarine channel which can be seen on the shelf. As the stratification, color and trace fossil of Khabour Formation is analogous to that of the Tanjero Formation. Therefore, by comparison, it is probable that the sandstone of the Khabour Formation belong mainly to low stand system tracts (low stand wedge) which deposited by sea level fall. In the Western Desert of Iraq, Al-Juboury and Al-Hadidy (2001a), divided the rock column of Khabour Formation into transgrssive and regressive sequences. It is possible that this division represents more detail subdivision of of the Lowstand system tract of the 
present study. In North America Bhattacharya and Willis (2001) described, in detail, a lowstand system tract in foreland basin during Cenomanian. The content of the lowstand is much similar to that of the Khabour and the Tanjero Formations in the view of lithology, trace fossil (cruziana and planolite) and sedimentary structures (cross bedding) (Fig.3).

\section{Environment comparison}

The environment of deposition of the Tanjero Formation is deep basinal (subduction or miogeosyncline) (Buday, 1980; Buday and Jassim 1987, Kettaneh and Sadik, 1989 and Lawa et al., 1998). Conversely, Karim (2004, 2005c) found that both lower and upper parts are deposited in shallow environment while the middle part is deposited in deep one. During deposition of the lower part the depth of the water is so lowered (by sea level fall) that some part of Tanjero Formation are deposited in shallow environment including near shore and slope environments (see Karim 2004). The lithology of Khabour Formation, at the outcrops, shows many factors of environment indicators. These indicators include trace fossils, bedding stratification and couplets in addition to sedimentary structures (Figs.3B, 4B, 8 and 10A) and fossils content (Fig.11A). In this connection Parker and Gaddo (1959 in Buday (1980) cited that the environment of the Khabour Formation, in Khleisia well no. 1, is indicated to be off shore. The lithology, in this well, is composed of the clastics intercalated with dolomite and limestone. When this lithology and that of Khabour area are concerned, the paleocurrent can be indicated toward the southwest as it became finer to that direction. The similar interlayers of limestone exist in sandstone of the Tanjero Formation in distal area of the basin.

In this basin, the interlayer of shale between sandstones bed on the shelf and slope, changed to marly limestone or limestone in the south of Sulaimanyia and Dokan area (basin plain). Karim (2005a) showed that the paleocurrent in the foreland basin of the Tanjero Formation is toward southwest and south. The same direction is cited for upper part of Khabour Formation by Buday (1980). He also mentioned that, in some case direction of currents was toward south. By analogy with lower part of Tanjero Formation it is possible that the basin of Khabour Formation has different environment ranging from shelf to slope environments.
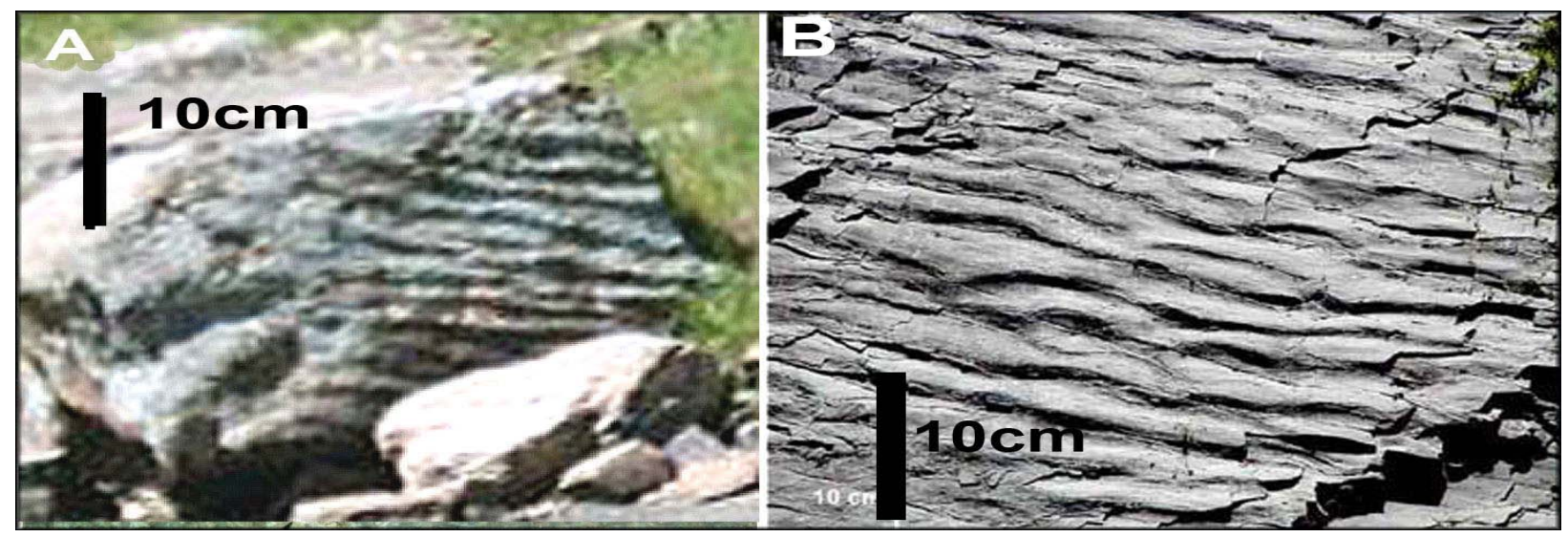

Fig. 10 : A) Longitudinal ripple marks found at $1 \mathrm{~km}$ west of Kaista village in Khabour Formation

B) same type of ripple marks found in Tanjero Formation( Taken from Karim, 2004). 

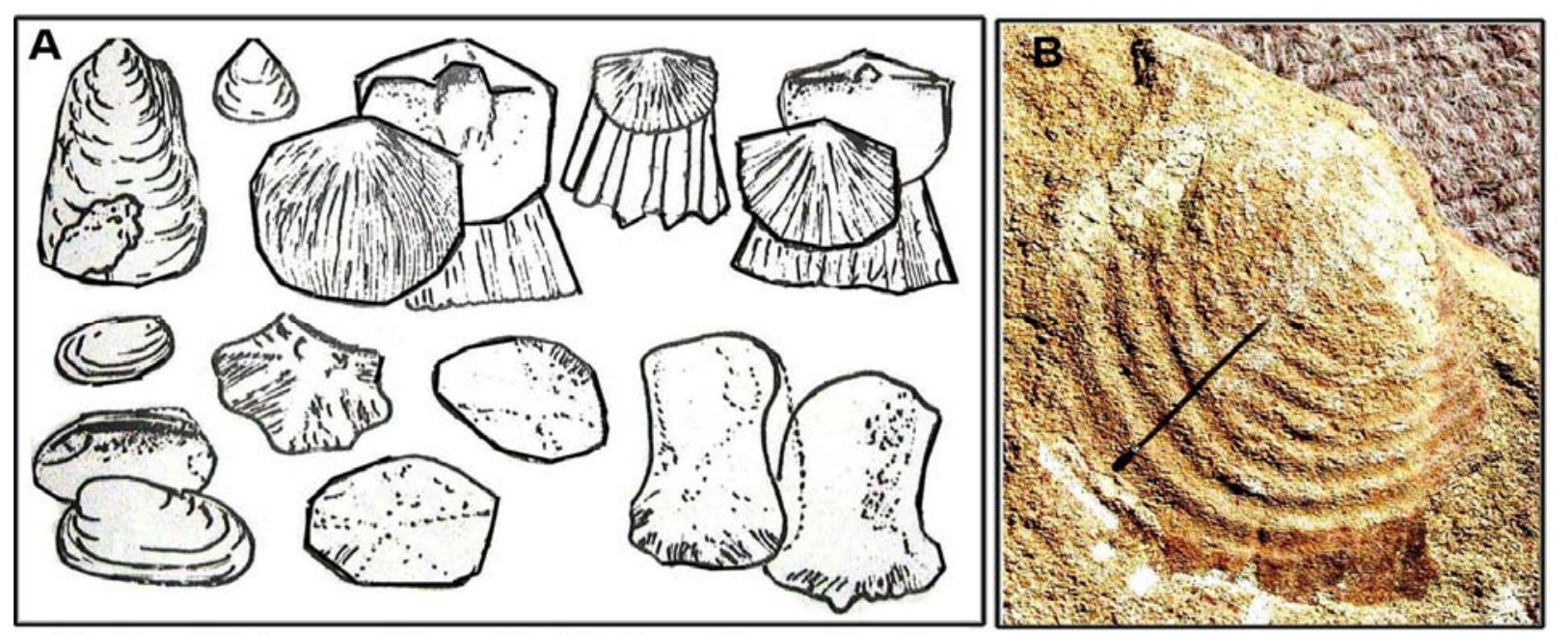

Fig. 11: A) Body fossils of pelecypods found in Khabour Qauartzite-Shale in Sinat Gorge (Al-Omari and Sadiq, 1977).

B) Pelecypods body fossil found in the lower part of Tanjero Formation in the Chaqchaq valley $2 \mathrm{~km}$ west of Qizlar Village on the peak of Girdy Gawra hill. (Taken from Karim, 2005).

The study has the following conclusions:

1- The result of this comparison revealed that Khabour Formation, in many aspects such as bedding characteristics, sedimentary structures, trace fossils, body fossils and association with red beds are analogous to lower part of Tanjero Formation.

2- The Khabour Formation was deposited in various environment include fluvial, deltaic, shelf, slope and basin plain. Among these, only the sediments of shelf and possibly slope environment are cropping out now.

3- The thick succession of sandstone with interbeds of shale of Khabour Formation was deposited in low stand system which created lowstand wedge.

4- The paleocurrent was possibly toward southwest and may be bordered by active fault during Ordovician.

5- Both formations are deposited in fault bounded basin with rapid mode of sedimentation. The source area was granitic or gnessoid body which possibly weathered in wet climate.

\section{REFERENCES}

Abdel-Kireem, M.R., 1986b. Planktonic Foraminifera and Stratigraphy of the Tanjero Formation (Maastrichtian), Northeastern Iraq. Micropaleontology, Vol. 32, No.3, pp.215-231.

Al-Juboury, A.I. and Al-Hadidy, A.H., 2001a. Lithofacies and Depositional Environment of the Khabour Formation, Western Desert. Raf. Jour. Sci. Vol. 12, No. 1. pp.34-42.

Al-Juboury, A.I. and Al-Hadidy, A.H., 2001b. Petrography and Diagenesis of the Khabour Sandstone, Western Iraq. Raf. Jour. Sci. Vol. 12, No. 2. pp.50-62. 
Al-Omari, F.S. and Sadiq, A., 1977. Geology of North Iraq, Mosul University Press.198p.

Al-Rawi, Y.T. and Al-Rawi, I.K., 2002. Tanjero Formation from Northeast and North Iraq. A Turbidite Example of Flysch Type. Proceeding of 15th Iraqi Geological Conference, 15-18 Dec. 2002, Baghdad.(abstract).

Al- Rawi, I.K.,1980. Sedimentology and Petrography of Tanjero Formation from North and Northeastern Iraq. Unpublished Ph.D. Thesis, University of Baghdad, 295p.

Bhattacharya, J.P. and Willis, B.J., 2001. Lowstand Delta in the Frontier Formation, Powder River Basin, Wyoming: Implications for Sequence Stratigraphic Models. AAPG Bulletin, Vol. 185.No. 2. pp.261-294.

Buday, T., 1980. Regional Geology of Iraq Stratigraphy, I.I.M Kassab and S.Z. Jassim (Eds) D.G. Geol. Surv. Min. Invest. Publ 1, 445p.

Buday, T. and Jassim, S.Z., 1987. The Regional Geology of Iraq: Tectonism Magmatism, and Metamorphism. I.I. Kassab and M.J. Abbas (Eds), Baghdad, 445 p.

Bellen, R.C., Van, Dunnington, H.V., Wetzel, R. and Morton, D., 1959. Lexique Stratigraphique, Interntional. Asie, Iraq,., 3c. 10a, 333 p.

Dickenson, W.R., Beard, S.l., Brakenridge, G.R., Erjavec, J.L., Ferguson, R.C., Inman, K.F., Lindbere, F.A. and Ryberge, P., 1983. Provenance of North American Phanerozoic Sandstone in Relation to Tectonic Setting. AAPG Bull.4. pp.222-235.

Doyle, P., Bennett, M.R. and Baxter, A.N., 2001. The Key to the Earth History: An Introduction to Stratigraphy. 2nd edition, John Wiley and Sons. New York. 293p

Jassim, S.Z., Hogopian, D. and Al-Hashimi, H., 1987. Geological Map of Iraq, Scale: 1:1000000 Series, Directorate General of Geological Survey and Mineral Investivigation, Baghdad, Iraq.

Jazza, I.M., 1991. Sedimentary Facies Analysis of the Tanjero Clastic Formation in Sulaimaniya District, Northeast Iraq. Unpubl. M.Sc thesis, Salahaddin University, 121p.

Karim, K.H., 2004. Basin Analysis of Tanjero Formation in Sulaimaniya Area, NE-Iraq. Unpublished Ph.D. thesis, University of Sulaimani, 135p.

Karim, K.H. and Surdashy, A.M., 2005a. Paleocurrent Analysis of Upper Cretaceous Zagros Foreland Basin: A Case Study for Tanjero Formation in Sulaimanyia Area, NE- Iraq, Iraqi Journal of Earth Science, , Vol. 5, No. 1, pp.30-44.

Karim, K.H. and Surdashy, A.M., 2005b. Sequence Stratigraphy of Upper Cretaceous Tanjero Formation in Sulanmaniya Area, NE-Iraq. KAJ, Vol.4. No.1. (in press).

Karim, K.H., 2005c. Environment of Tanjero Formation as Inferred from Sedimentary Structures in Sulaimanyia Area, Kurdistan Region, NE-Iraq. KAJ(Kurdistan Academician Journal) Vol.4, No.1.(in press).

Kennedy, W.J., 1975. Trace Fossils in Carbonate Rocks, in: Frey, R.W. The Study of Trace Fossils, Springer-Verlag, Berlin, New York, 560p.

Kettaneh, Y.A. and Sadik, A.J., 1989. Mineralogy and Geochemistry of Shiranish Formation, North Iraq. Journal of Iraqi Geological Society, Vol. 22, No. 1.

Mial, A.D., 1990. Principles of Sedimentary Basin Analysis, 2nd, Springer-Verlage, 668p.

Lawa, F.A., Al-Karadakhi, A.I, Ismail, K.M., 1998. An Interfingering of the Upper Cretaceous Rocks from Chwarta-Mawat Region, NE-Iraq, and Iraqi Geol. Jour. Vol.31, No.2.

Pettijohn, F.J., 1975. Sedimentary Rocks. 3rd edition, Harper and Row Publ. Co., 627p. 